\title{
『東方見聞録』における酒に 関する一考察
}

マルコポーロの「東方見聞録」は, 13 世紀末の 25 年間にわたるシルクロード周辺地域を含む元朝中国や 南海諸島でつくられていた酒と光の飲酒風俗を現在に伝える貴重な資料である。

著者は, 同書に記録された酒の種類や製法, 地域などの情報から, ユーラシア大陸における酒文化圈の形 成を次の類型から説明した。(1)ユーラシア大陸ワイン街道, (2)米酒文化圈, (3)乳酒文化圈, (4)楖子酒文化圈, これらの酒文化圈をマルコポーロの旅行地図上に印した,「酒文化圈マップ」(Fig. 1) は, 著者の独創史料 である。

\section{高 山 卓 美}

\section{緒言 \\ マルコ・ポーロは, 1270 年ベニスを出発し,} 1271 年末シリアのライアス（現在のアヤス市）から 西アジア・中央アジアを縦断・横断して，1274 年元 朝の上都を訪れ 17 年を過ごした後, 1290 年泉州を船 出してから海路で 1293 年ホルムズに達し, 陸路をと りダブリス経由でトレビゾンデに進み, 海路で 1295 年ベニスへ㷌還している2)。

その間, 彼自身が見聞した各地の酒や酒俗を『東方 見聞録』に書き残している。これらの記録は, 13 世 紀末の陸シルクロード周辺のオアシス都市と国々や海 シルクロード沿いにある島々の酒の種類や酒俗などの 酒文化を, 今に伝えて呉れる極めて貴重な史料である。 13 世紀末の酒の種類とその製法およびその分布を明 らかにするするために『東方見聞録』から酒類の記録 を抽出して検討した。

\section{I.『東方見聞録』中の酒類の記録の抽出}

マルコ・ポーロ旅行記の古写本, 古版本は百数十種 あると云われる。青木訳『東方見聞録』1 ${ }^{1)}$ 愛宕訳 『東方見聞録』2)の他に, 見聞録中には中国の記事が多 いので, 中国の馮（Fengフォン）訳『馬可波羅行
紀』3) のE氏訳本を選び，その中から酒類および酒 俗に関する記録を抽出した。

\section{II. 抽出された酒類の記録}

抽出した酒の種類は, 葡萄酒（葡萄果実を含む）, 米酒, 蒸留酒, 楖子酒, 乳酒, およびその他の酒の 6 種類であった。これ以外に酒の記録が 4 地域で見られ たが，酒の有無を示すもので，その種類は不明であっ た。これらの酒類に関する記録がある地域は，番号を 付けてマルコ・ポーロの旅行行程図中に挿入して示し た（Fig. 1)。なお，本報では酒俗についての検討結 果は割愛した。地名は, 愛宕訳の日本名で表わし括弧 内に馮訳の中国名で示した。

\section{III. 酒類についての考察}

葡萄酒, 米酒, 蒸留酒, 楖子酒, 乳酒, およびその 他の酒の製法や分布について考察した。なお, 上都, 大都の宮中で使用された酒については，特に項目を設 けて考察した。

\section{1. 葡萄及び葡萄酒}

次の 8 地域に葡萄および葡萄酒の記述があった。 (2)ペルシャ 8 王国（波斯之 8 国）：

青木「葡萄酒を産する」1), 愛宕「ぶどう酒が豊

The Consideration on the Alcohol Beverages in "The Travels of Marco Polo"

Takumi TAKAYAMA (The former takara syuzo Co., Ltd.) 


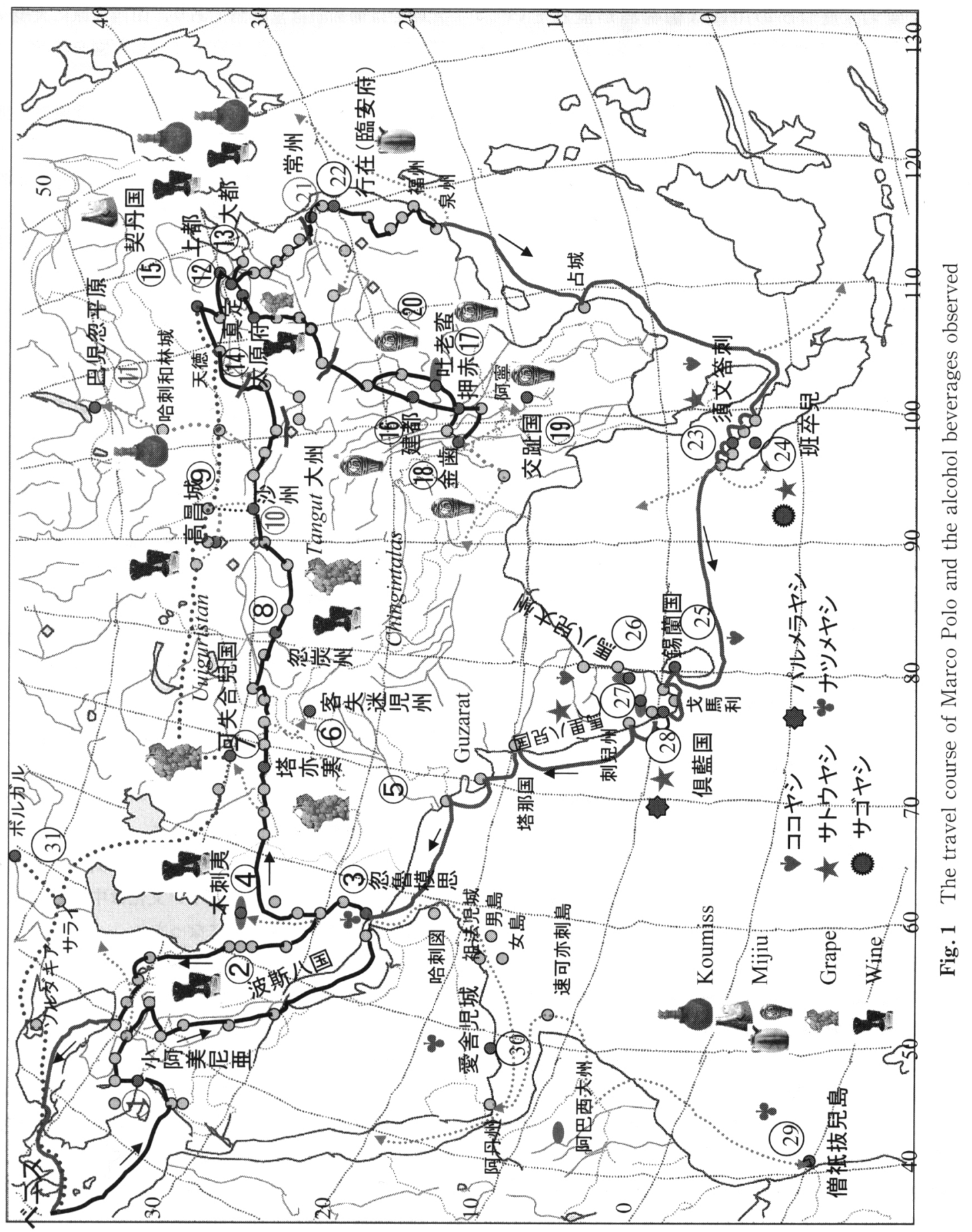


富」2)，住民はイスラム教徒。

\section{（4）ムレヘット (木刺夷) 地方：}

青木, 愛宕「幾つかの川に葡萄酒が流れてい た」王2), 馮「有管流通酒」3), 住民はイスラム教徒。

(5) タイカン (塔亦寒) から 3 日目の地域 :

青木, 愛宕, 馮「葡萄などの果物がある」 $\rfloor^{1,2,3)}$, 住 民はイスラム教徒。

（7）カスカール王国（可失合兒国）：

青木, 馮「葡萄園をもつ」 $\rfloor^{1,3)}$, 住民はイスラム教徒, 少数のキリスト教徒がいる。

(8)大国コータン (忽炭州)：

青木「葡萄酒なども豊富」1), 愛宕, 馮「葡萄園も 多く見かける」 $\rfloor^{2,3)}$ ，住民はイスラム教徒。

(9)イコグリスターン国（高昌ウイグル国）：

愛宕「上質の葡萄酒を産出する」 ${ }^{2}$, 住民は偶像教 徒, キリスト教, 少数のイスラム教徒。

(14) 大都市ジョンジュー（溷州大城）からタイユアン フ王国 (太原府)：

蘆溝河からジョンジュー, タイユアンフまで, 青木, 愛宕, 馮「葡萄園」1,2,3) が続いており, 太原府につい ては青木, 愛宕, 馮「葡萄園が多く, 葡萄酒の醸造も 巨額に上り，カタイ（契丹）国で唯一つの葡萄酒生産 地で，全国に供給される」1,2,3) とある。

（22）キンサイ市（蛮子国都行在城）（南宋の首都臨安 府) :

青木, 愛宕, 馮「此の地方は, 葡萄も葡萄酒もでき ないが外地から上質の葡萄酒や干し葡萄が輸入される。 この地の人々は米に香料を加えた酒を常用し, 葡萄酒 はあまり嗜好しない」1,2,3) とある。

ペルシャ，ムレヘット，タイカン（後述）およびコ ータンでは，住民がイスラム教徒であるにも拘わらず 葡萄酒が造られていた。

西漢の武帝（BC140〜 BC 87）時代, 大苑国では大 規模な葡萄栽培と葡萄酒造りが行われており，葡萄が 中原に伝えられた ${ }^{4)}$ 。後晋の高祖（936〜942）の時, 于闐に派遣された高居誨は「葡萄で酒を造るが，紫酒 や青酒があり, 製法は解らないが, 美味しい」と書い ている5)。

唐朝の太宗（627〜 649）時代, 高昌城を破った時, 葡萄と葡萄酒の製法も手に入れている ${ }^{6)}$ 。太宗は, 自 ら葡萄酒を造り, 学士に賞として贈り,また宮廷中宴 でも飲むなど，必備の酒であった7)。また西安の酒楼
では胡姫を侍らせ葡萄酒が飲まれた。山西省の太原府, 平陽の葡萄酒は, 唐朝以来有名であった ${ }^{8)}$ 。

元朝では葡萄酒は宮廷酒であり, 山西太原に大規模 な葡萄園を開園し，大都の宮中にも葡萄園を建設した といわれる7)。

葡萄は小アジア原産であり, BC3000 頃近東に伝播 し干し葡萄や葡萄酒が造られた。アケメネス・ペルシ ヤ（BC559〜BC 330）では葡萄が植えられ，葡萄酒 が宮廷建設労働者に労賃として支給された。次のアレ クサンドル大王領（BC336～BC323）, セレウスコ朝 (BC305〜 BC64), パルテイア $(\mathrm{BC} 250 \sim \mathrm{AD} 226)$ や バクトリア王国（BC250～BC139）でも葡萄や果樹の 栽培が盛んであった。ソグデイアナのソグド商人の町 ペンジケントの壁画（5～8 世紀，タジキスタン民族 考古博物館）にはワインを注ぐ人物が描かれている。 葡萄酒造りは中央アジア西部から, 更に東部のオアシ ス都市へと, シルクロードに沿って東へ伝播し, 紀元 前 2 世紀に漢朝に伝わり, 唐代には西安で飲まれ, 元 の時代に大都（北京）に達した。

この陸のシルクロードに沿って出来た葡萄とワイン の道は, “ューラシア大陸のワイン街道” と命名した い。しかし，7 世紀イスラム教の成立によって，その 禁酒の戒律は, その後の葡萄と葡萄酒の発展に大きな 影響を与えた。

西アジアは 7 世紀に，小アジアは 11 世紀に，中央 アジア西部は 9 世紀に, 中央アジア東部は 11 世紀に イスラム化されたので, マルコ・ポーロの通った地域 の住民は，殆どがイスラム教徒であった。ただ，トル ファンの西ウイグル王国のイスラム化は，15世紀ま で遅れた。イスラム圈ではワイン文化は中断し，生食 用葡萄が発展進歩することになった。

製法は, 唐・蘇敬撰『新修本草』, 金・元好問撰 『葡萄酒賦』に見えるが，北宋・朱翼中著『北山酒経』 下巻にも見られる (Fig. 2)。

\section{2. 米酒}

マルコ・ポーロは，7地域の米酒をとりあげ，その 原料と醸法を簡単に記述している。原料と製法を模式 図にして示した（Fig. 3-1〜3-7）。

原料は, ガインドウ地方（建都州）では米, 麦と香 料, 他の地では総べて米と香料だけであるが, 酒曲は 総べての地で記載されていない。この香料とは一体何 であろうか。また酒曲は何故記載されなかったのであ 


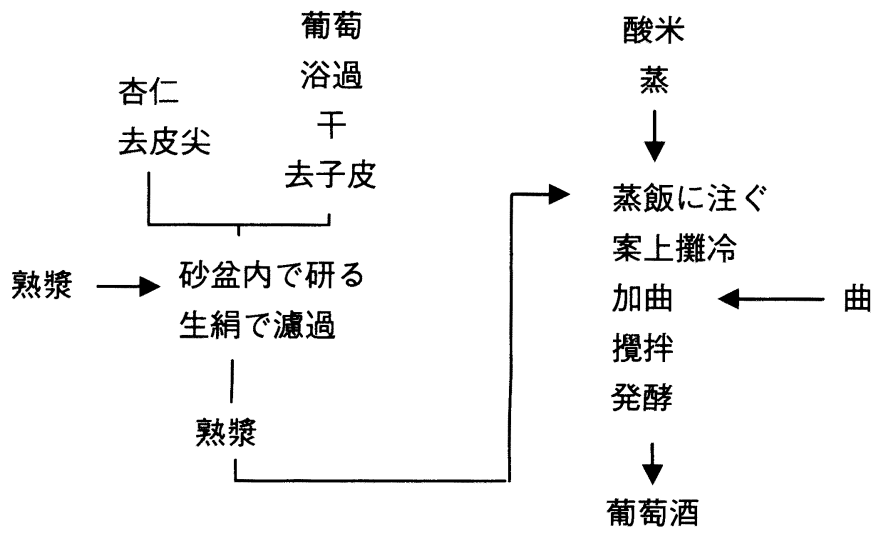

Fig. 2 蒲萄酒法

北宋・朱翼中『北山酒経』巻下

中村 喬訳：中国の酒経，1991, 東洋文庫

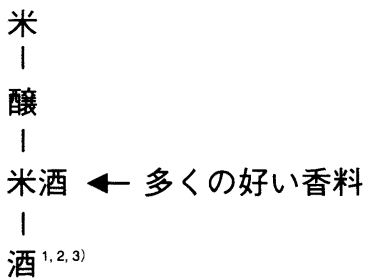

Fig. 3-1 契丹人の酒 (15)

酒質：よく澄んでいて,うまい, 非常に強く 早く酔いが回る ${ }^{1)}$ 。芳醇な味, どの酒より飲 み心地よい, 佳く澄んできめ細かい, 相当度 が強く他の酒より酔いが早い2)。味佳, 色清 爽目, 味極濃, 較他酒為易酔 3 。

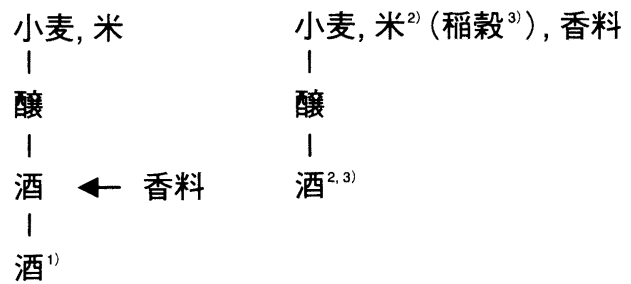

Fig. 3-2 建都州の酒 (16)

酒質：なかないける1)。頗る佳味,2,3。

ろうか。

『北山酒経』(巻二, 総論 $)^{91} に 「$ 曲用香葯, 大抵辛 香発散而已」とあり，朱翼中は曲に香葯を加えると， 辛味と芳香が発せられることを強調している。彼の観 点からすると，“香料は香葯”を指していると解する

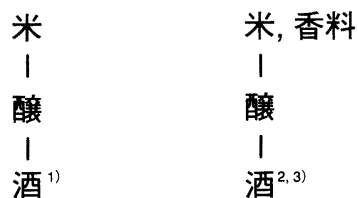

Fig. 3-3 押赤の酒 (17)

酒質：澄んだ旨いもの ${ }^{1)}$ 。透明, 風味が有り, 匍萄酒並みに飲める2)。味は甚だ佳い3)

ことができる。香葯と米又は麦で酒曲を造るので, 原 料として酒曲を挙げなかったと思われる。

（15）カタイ人の飲用する酒（契丹人所飲之酒）：

カタイ人とは契丹人のことで遼（916～1125）を建 国したが，女真族（満州族）により滅ぼされた。マル コ・ポーロは, 金国の領土内に居住する人達のことを 言っている。

米と小曲で造る小曲醸米酒に, 多くの好い香料（香 葯）を加えた酒（Fig. 3-1）であるから，冷浸法或は 加葯醸製法で造られる药酒（Fig. 4) と見られる。芳 醇な味で，よく澄んで，度数が高く，酔いが早く回る 酒であった。

(16) ガインドウ地方（建都州, 現在の四川省西昌市）

の酒 :

小麦, 米 (稲穀) と香料で醸す酒（Fig. 3-2）であ る。主原料は米で, 小麦 (白麺) と香料（香葯）で造 る小曲（例えば法麹9), Fig. 5), 或は小麦 (白麺), 香料と糯米粉とで造る小曲（例えば金波曲 ${ }^{9)}$ ，Fig. 6) を用いて醸造した小曲醸米酒であろう。頗る佳味な酒 


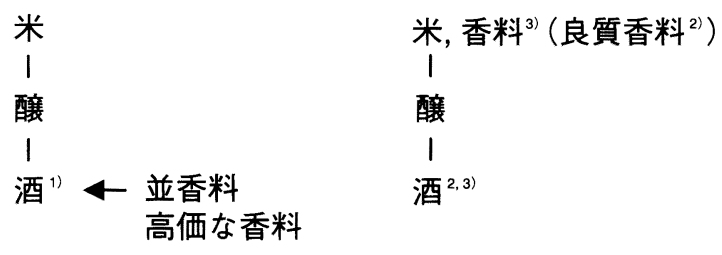

Fig. 3-4 金歯州の酒(18)

a）酒質：味よい1)。風味あり ${ }^{2)}$ 。味甚佳 ${ }^{3)}$ 。

b）高い香料をふんだんに使った飲物がある11

值段のはった上級酒がある2)

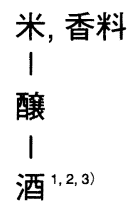

Fig. 3-5 交趾国の酒(19)

酒質：良質な酒 ${ }^{2)}$ 。味甚(佳 ${ }^{2}$ 。

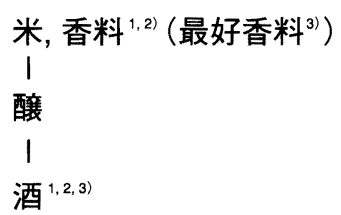

Fig. 3-6 秃落蛮の酒 $(20)$

酒質：良質の酒 ${ }^{2)}$ 。味甚佳 ${ }^{3)}$ 。

\section{米, 香料 \\ । \\ 醸 \\ 1 \\ 酒 ${ }^{1,2)}:$ 独特の酒 ${ }^{2)}$ \\ 米酒 ${ }^{3)}$ : 原料記載なし}

Fig. 3-7 蛮子国都行在（臨安府）の酒 (22)

であった。

蘇東玻（1037～1101）は，嶺南（広東）では自分で 酒を醸し，その醸造法を「東玻酒経」に書いているが, 彼は眉州眉山（四川省）の出身であり，四川省でも同 じような酒造法であったかも知れない (Fig. 7-1,

Fig. 7-2)。

（17）ヤチ王国（押赤城，現在の昆明）：

米と香料で醸す酒（Fig. 3-3）である。主原料は米 で，米と香料（香葯）で造った小曲（例えば白型曲 ${ }^{9}$, Fig. 8）で醉した小曲醸米酒であろう。透明で，葡萄
酒並みに飲む事が出来て，味は甚だ佳い酒であった。 （18）大ザルダンダン地方（金歯州，元代の永昌府，現 在の保山市) :

永昌には氐姜系のイ族などの祖先, 百越系の夕イ系 民族の祖先，モンクメール系民族の祖先やインド人が いた（常據著：華陽国志・第四南中志：西晋～東晋)。 金歯百夷とは夕イ系民族のことで，歯に黄金をかぶせ， あるいは漆をかける風習があるので金歯蛮と呼ばれた。 米と香料で醸す酒（Fig. 3-4）である。主原料は米 で，米と香料（香葯）で造った小曲（例えば前述の白 醪曲）で醸した小曲醸米酒であろう。值段の張った上 級酒があり，これは高級な香葯をふんだんに使った小 曲で醸した酒であったと思われる。

(19)大カウジグー地方（交趾国，雲南南部からラオス 北西部の地）：

米と香料で醸す酒（Fig. 3-5）である。主原料は米 で，米と香料（香葯）で造った小曲（例えば前述の白 醪曲）で醉した小曲䁔米酒であろう。

（20）トロマン地方（秃落蠻州，雲南北部で四川省叙州 に近い地方)：

米と香料で醸す酒（Fig. 3-6）である。主原料は米 で，米と香料（香葯）で造った小曲（例えば前述の白 醪曲）で醸した小曲醸米酒であろう。

雲南の小曲醸米酒の技術は, 蜀印度道（西南シルク ロード）を通じて蜀国から伝播したものと，広東の南 越国から貴州の夜郎国を経て保山にいたる交易路を通 じて，長江以南の越人の移動や交易によってもたらさ れたものとがある。特に，ザルダンダン地方には， 『南方草木状』10)に見られる南海（広東，広西地方） の酒が伝播していたと思われる。

（22）キンサイ市（蠻子国都行在城，南宋の首都，現在 の杭州) の酒： 


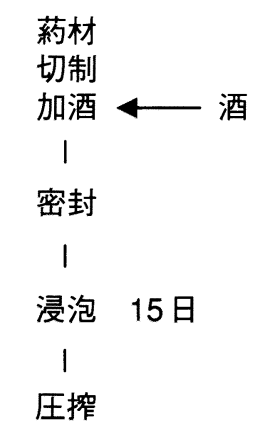

(冷浸法)

Fig. 4 契丹人の飲む酒

薬酒の製法

陳 主編：中国薬酒大全, 1991, 上海科学技術 出版
米: 糯米, 黄粘米 水浸泡

蒸募

粥

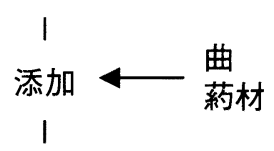

糖化発酵

圧搾

（加葯醸制法） 出版

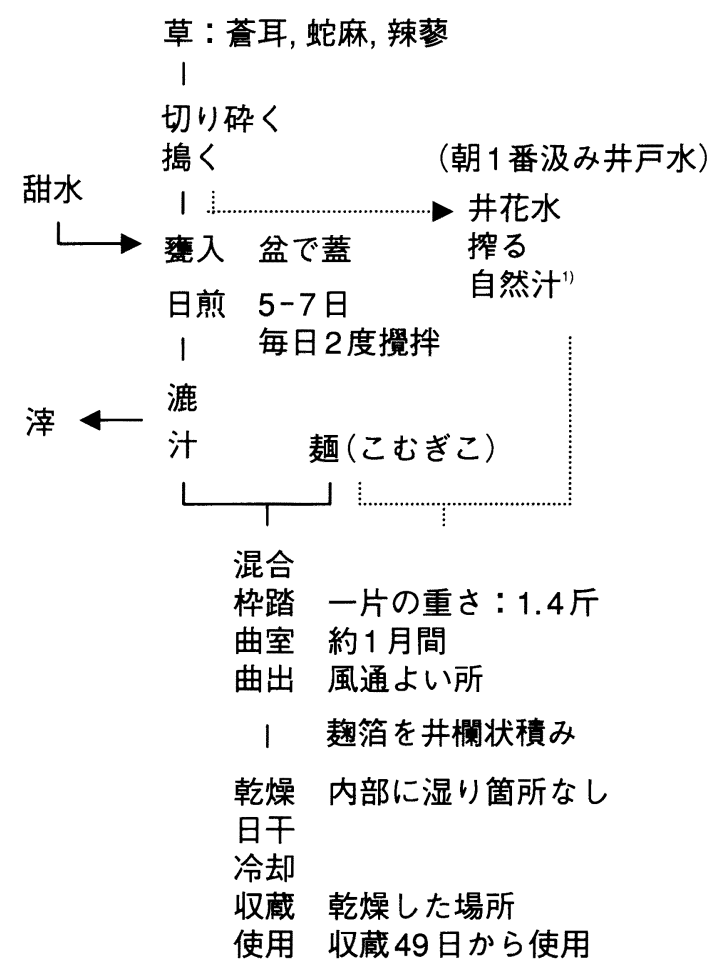

Fig. 5 建都州の小麦・米・香料で造る酒

麺と香葯で造る䡘：法趜（北山酒経）

1）漉汁の代わりに自然汁を使用すると酒味は 辛辣（ぴりっ）となる。

米と香料で造った酒（Fig. 3-7）であった。主原料 は米で, 米と香料（香葯）とで造った小曲で醸した小 曲酻米酒であろう。

南宋（1127～1278）の首都・臨安では, 「人々は米 に香料を加えた酒を常用し」1,3), 愛宕「人久は米に香 料を加えた独特の酒を常用し」2)，また「米と香料で 醸造した酒のみを，専門に売る店があり」1,2,3)，「その 価格は大変安い $ل^{1,3)}$ とある。西湖游宴等で酒消費量が 増大し, 陸游（南宋, 山陽の人, 1125 1210）は「城 内酒屋千百家」とその情景を述べている。城内だけで なく，城外では農民が冬季淋飯酒（Fig. 9）を造り, 煎煮した酒 (大酒) を夏季城内に運搬販売したし，越 州蓬萊春 (紹興酒) (Fig. 10) や竹叶酒, 瑞露酒など の名酒があったと言われている11)

愛宕の「独特の酒」の正体は不明である。浙江省吳 興県の出身である北宋（960～1127）の朱翼中は, 臥 漿（乳酸発酵液）や乾酵（発酵醪の泡）を使用して酒

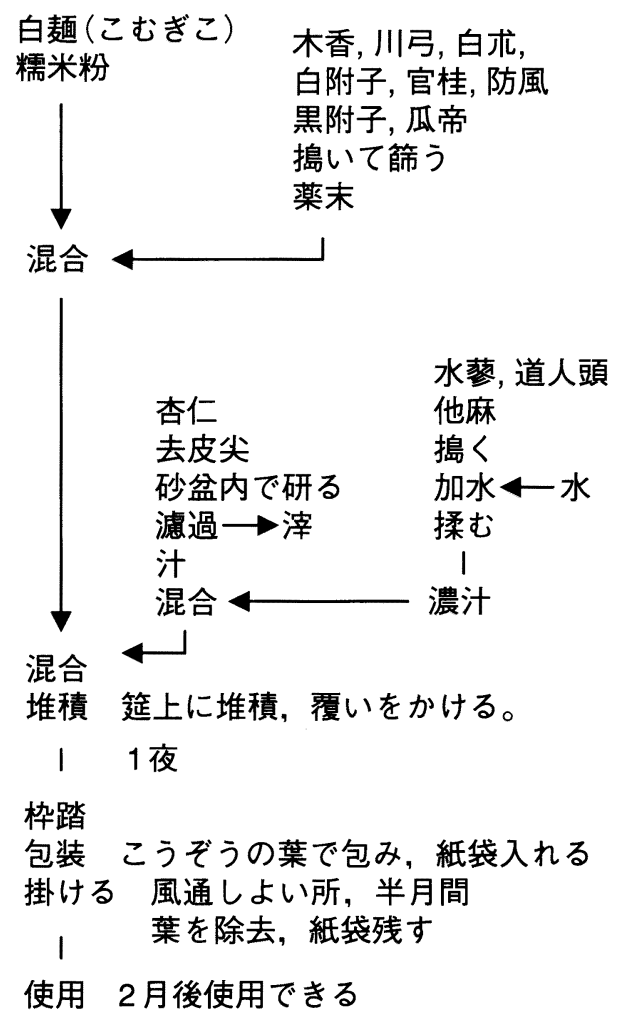

Fig. 6 建都州の小麦・米・香料で造る酒

湎と糯米粉と香葯で造る錮：金波曲（北山酒 経) 


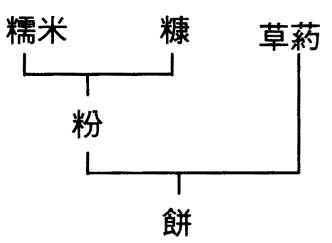

麺(こむぎこ)

打ち寝かせ

添加

捏ね合わせ

1

蒸す：十字に裂けさす

।

培養：縄で穿つ

। 風に乾かす

敖

Fig. 7-1 建都州の小麦，米，香料で造る酒 蘇東玻の餅と麹

1）餅曲は発酵が激しい，風曲は発酵が穏やか 中村 喬訳：東玻酒経, 1991，(秼平凡社

米3斗

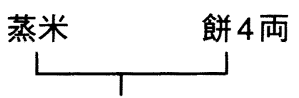

初仕込 搭窩，3日で酒漿満つ

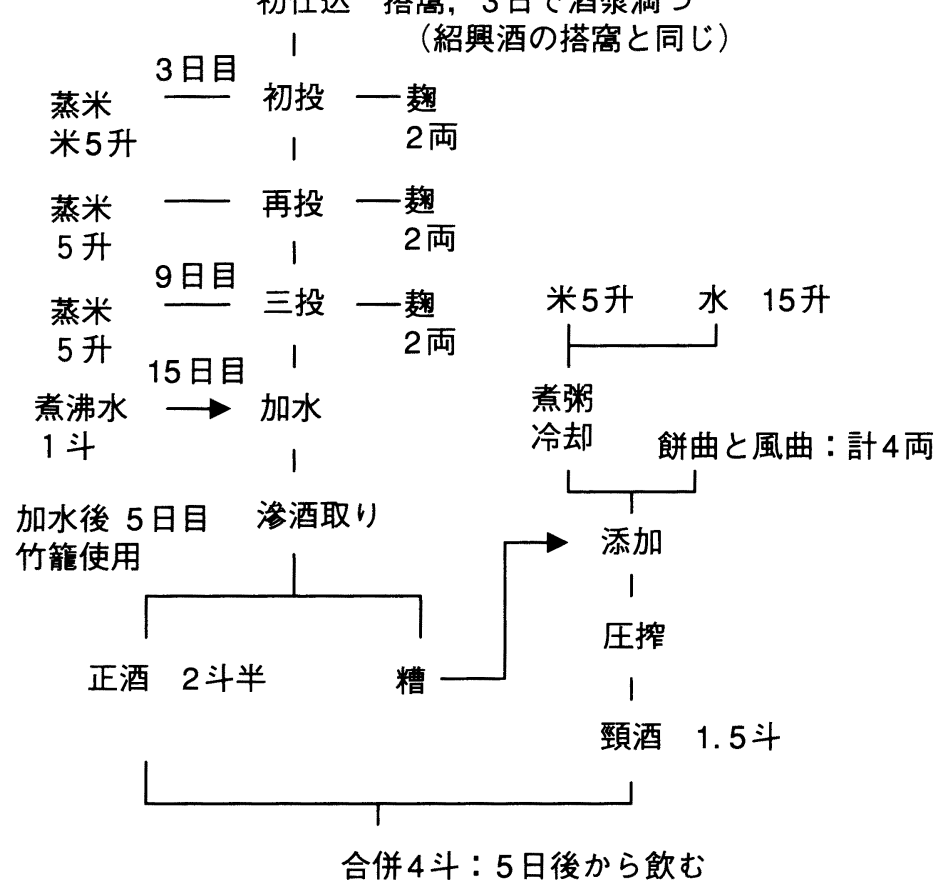

Fig. 7-2 建都州の小麦, 米, 香料で造る酒 蘇東玻の酒造法

中村 喬訳：東玻酒経，1991，(侏平凡社 


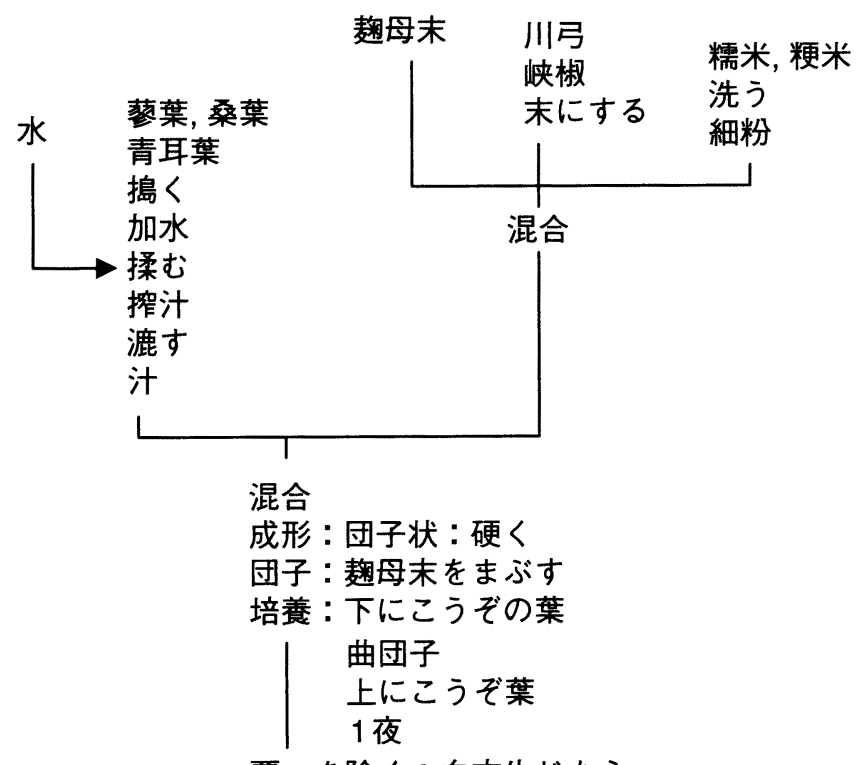

覆いを除く：白衣生じたら

天日干し：5-7日間

籠入れ：通風良き所に掛ける

1

使用: 米 1 斗当り 3 両

半年以上保存した曲は

米 1 斗当り 2.5 両

Fig. 8 米と香药で造る麹

白醪曲 (北山酒経)

母を造り，酘（添）を行い，上槽後㳯引きして殺菌す る酒造法を書き残しているが, 京式（開封式）と比較 して論じており，南宋も北宋の技術を受けているから 独特の酒はこのような醸造法 (Fig. 11) による酒で あったと思われる。

\section{3. 蒸留酒}

マルコ・ポーロは, 蒸留酒については多く書き残し ていない。

(2)ペルシャ 8 王国（波斯之 8 国）

愛宕「イスラーム教徒が，禁酒戒をまげて解釈して いる旨昖答えしたい。…酒を火にかけいくぶんでも蒸 発して甘味が出てきさえすればこれを飲んでも戒律を 犯すことにならないというのである。」吕と訳している。 加熱してアルコールを蒸発させた残酒は, 酒ではない ので飲むことができるというのである。

(5) タイカン (塔亦寒, ) から 3 日目の地スカセム市 (訖瑟摩)：

タイカン市（アフガニスタン，アム河上流クンドウ

第 102 巻 第 3 号

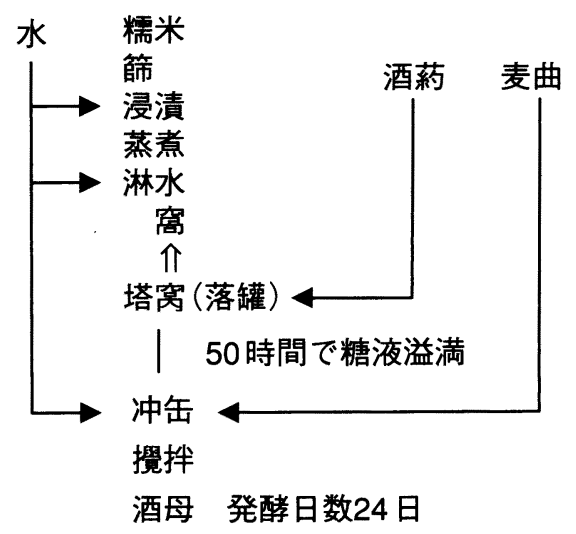

Fig. 9 淋飯酒の製法

ズ地方のタリカン市) からスカセム市（アフガニスタ ン, アム河源流地域バダクシャンに至る途中のキシ ム）に向かう道中は, 「葡萄の豊かにみのる土地で, 住民はイスラム教徒である」帛, が, 青木「酒はうま く, 彼ら自身大酒飲みなので, 酒屋に入り浸ってい 


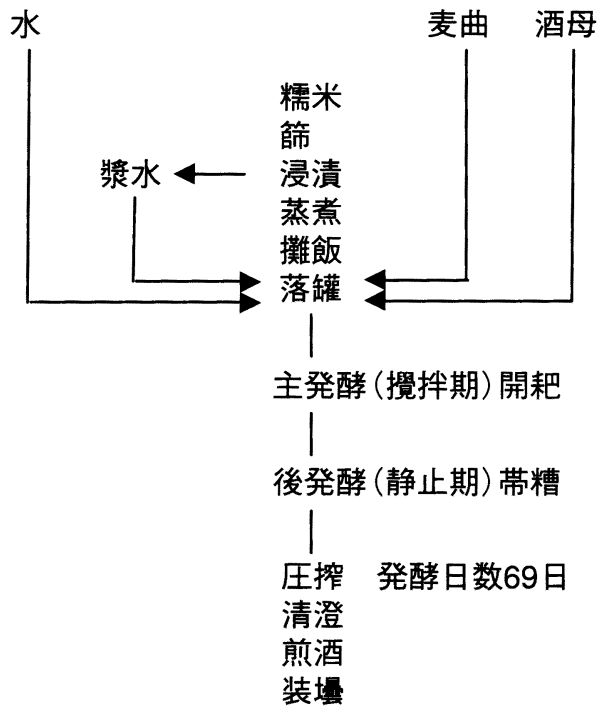

Fig. 10 元紅酒, 加飯酒の製法

開耙：攪汼

帯糟：主発酵終了醪を瓶に分注すること
る」 $\rfloor^{1)}$, 愛宕「生来酒飲みの上に, 良質の蒸留酒があ るときているから，暇さえあれば酒宴に耽ってい る」 $\rfloor^{2)}$, 馮「居民…, 嗜飲酒, 善飲, 飲輙致酔, 其酒 者飲 \3)。青木は酒, 愛宕は蒸留酒, 馮は「其酒煮飲」 と訳している。馮氏の「其酒煮飲」は，煮て得られる 蒸留酒を指すと思われ, タイカン地方には蒸留酒が存 在したことになる。そして，“煮る酒”は恐らく葡萄 酒であったであろう。

マルコ・ポーロは, これ以外の地では蒸留酒につい て書き残していない。

中国では，李時珍は『本草綱目』谷部・巻二十五 （1596）で「葡萄酒有二様：醸成者味佳，有焼酒法者 大毒。焼者, 取葡萄数十斤, 同大曲醸酢, 取入㽬蒸之, 以器承其滴露, 紅色可愛。古者西域造之, 唐時破高昌, 始得其法」と述べており，唐は高昌国を破った時（西 暦 640), 葡萄酒の蒸留法（Fig. 12）を始めて知った としている ${ }^{6)}$ 。その後, 金朝の世宗代（1161 頃）の蒸

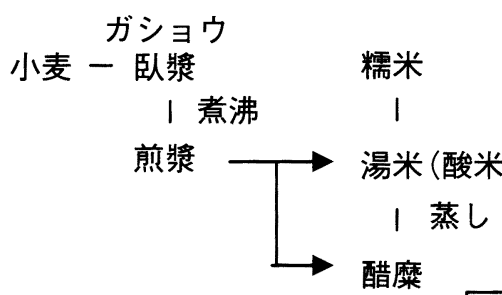

1

トペイ

糯米

$\downarrow$

甜糜

(酸蒸米)

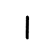

余米 (酒母)

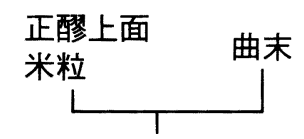

大曲

小曲

麦蘖

挿飯

酸：夏；3(5 ?)７回

I 冬; 4 6 回

圧㩁：発酵日数寒時：24～25日

温冷時：半月

暑時：7〜8日

滓引き：3〜 5 日

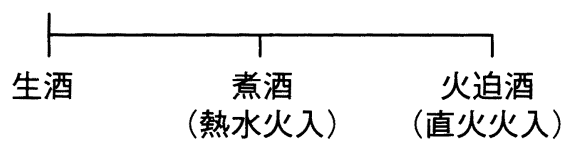

Fig. 11 北山酒経 (1117) 巻下の酒造法

中村 喬訳：中国の酒経, 1991, (侏平凡社

当時北方では酵母は使用しなかった。

則ち，伝統的浸曲法醸造であった。 
留鍋 (Fig. 13) ${ }^{12)}$ が出土し, また敦煌棌林窟の壁画 (西夏時代：1038～1127) に蒸留器と蒸留風景が描か れており (Fig. 14) ${ }^{13)}$ ，元朝世祖代（1260～1294）の 『居家必用事類全集』には「南蛮焼酒法」(Fig. 15) が詳細に記述されている ${ }^{14)}$ 。

マルコ・ポーロは1290 年末, 泉州から海路で州国 したが，40 年後忽思慧は『飲膳正要』（1330）の中で 「南方から阿刺吉酒（焼酒）が伝えられた」と書き残 している。

近年, 河北省劉伶酒廠の醸造工場で, 宋・金代 （1126）の古い焼鍋遺跡 ${ }^{15)}$ が発見され，また江西省李 渡無形堂酒業有限公司でも元代後期（1310～1368，鄧 少平先生の口答による。2006.9）の焼酒作業場遺跡が 発見されている ${ }^{16)}$

以上のように, 中国では元朝時代, 既に焼酒があっ たと考えられるが, マルコ・ポーロは, 蒸留酒につい て書き残さなかった。何故であろうか？
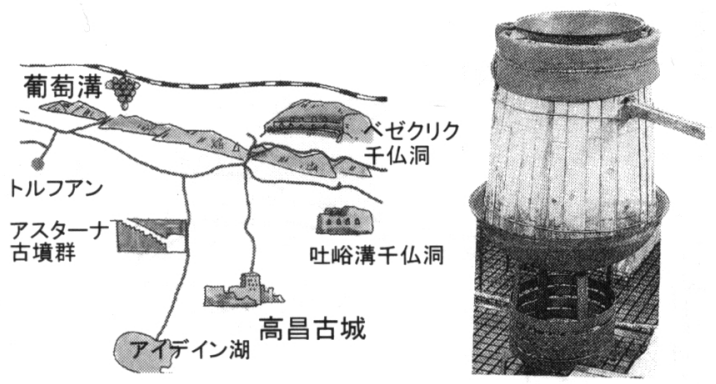

Fig. 12 トルフアンの高昌城と蒸留器（想像図） 640 年, 唐は高昌国を破る

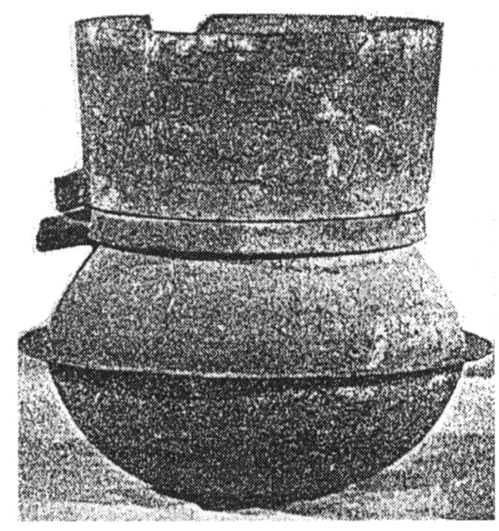

Fig. 13 河北省青龍県で出土した蒸留鍋 金代（1161 頃）
オアシス・シルクロード沿いの蒸留酒については, 極めて資料が少ない。13〜14 世紀，ダマスカスの Al -Dimashki（1256〜1327）がバラ香水の蒸留器（Fig. 16）を書き残している他，パキスタンのタキシーラ付 近の遺跡で BC2〜AD5 世紀の地層から蒸留器 (Fig. 17, Fig. 18）が発見されているくらいである ${ }^{17) 。 こ の ~}$ 地方は, クシャン王朝 $(45 \sim 445)$ 時代, 医学者チャ ラカらが活躍したアートレーヤ学派の中心地であった から, 薬学の研究に使用された蒸留器かも知れない。

\section{4. 椰子酒}

マルコ・ポーロは, 以下の 8 地域で柬椰子酒と楖子 酒を見ている。

（3）ホルモズ市（忽魯模思城）：

青木「香料入り雵楖子の酒，ひどく酔うし下痢を起 こす」1)。愛宕, 馮「柬椰子の実に多量の香料を混ぜ て造るが，とても質が良い。下痢を起こすが，体に良

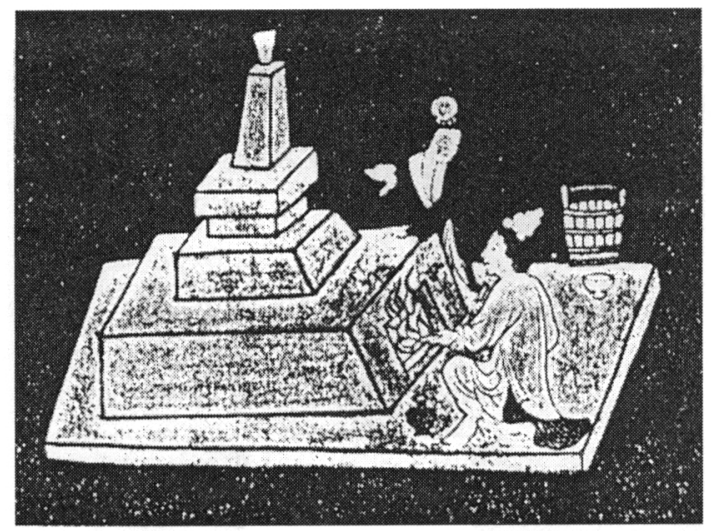

Fig. 14 敦煌榆林窟の壁画：蒸留器 西夏代（1038～1127）

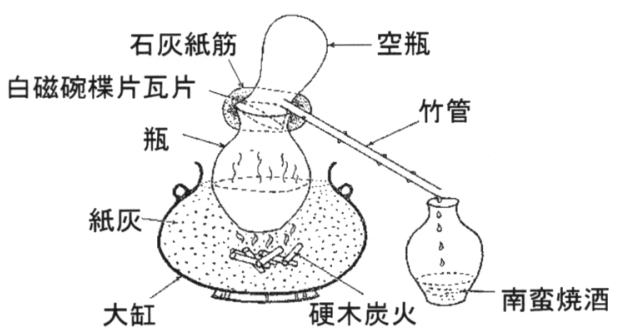

Fig. 15 居家必要事類全集（元代初期～中期）の南蛮 焼酒法による蒸留器 菅間誠之助：第三の酒，1975，(株)朝日ソノラ २ 


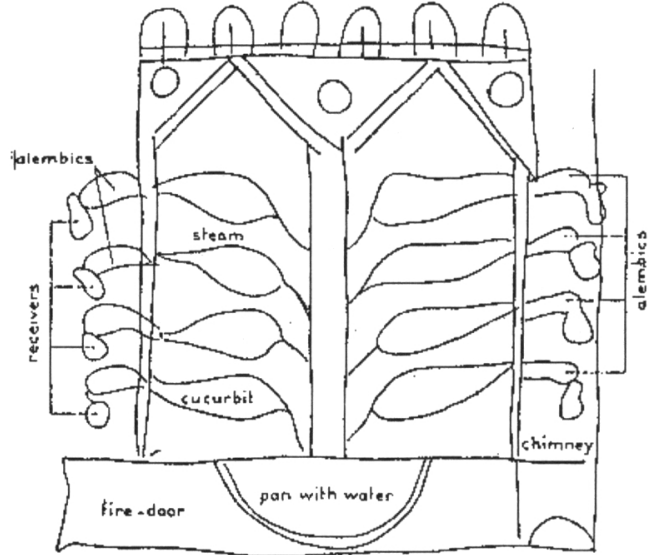

Fig. 16 Al-Dimashki'S steam oven for Rose Water (1256 1327), Syria, Damascus

R. J. Forbes : Short History of the Art of Distillation, 1948

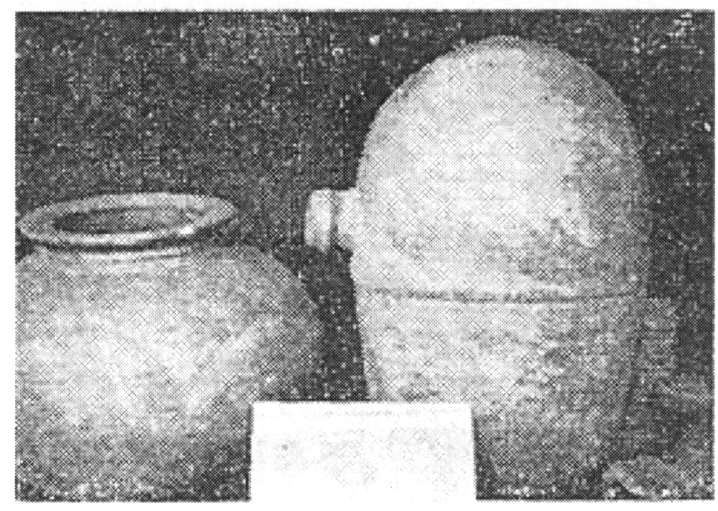

Fig. 17 タキシーラ付近の遺跡から出土した蒸留器 $\mathrm{BC} 2$ 世紀から AD5 世紀の地層：タキシーラ博 物館
く血行を良くする」2,3) とある。香料は，何であったか 不明である。

ナツメヤシ Phoenix dactylifera は, 北アフリカか らインダス河まで広く分布し, 古くから乾燥地帯の食 糧として貴重な植物であった。エジプトでは BC2000 年頃, 既に栽培されていた ${ }^{18)}$ 。そのナツメヤシの実か ら酒が造られており，BC1900 年頃のテーべの壁画 (Fig. 19) にナツメヤシ酒の製造法（Fig. 20）が描か れている ${ }^{19)}$ 。バビロニア地方でも BC5 世紀頃のナッ メヤシ酒の記録がある20)。

(23) サマトラ王国（須文答刺国）：

青木, 愛宕, 馮「樹の枝を切り, $\cdots$ 滴った樹液は 1 昼夜で容器一杯になる。この酒はなかなかのもので白 と赤の 2 種類がある $\rfloor^{1,2,3)}$ 。また青木，愛宕「人間の 頭ほどの大きさで味の旨いインド胡桃が豊富にとれる。 新鮮なのには，核の内部に液が詰まって… $\rfloor^{1,2)}$ とある。

白い樹液のとれる樹はココヤシ Cocos nucifera で, 赤い樹液のとれる樹はサトウヤシ Arenga pinnata （馬氏は，Arenga saccharifera）と推定される。「イ ンド胡桃のなる樹」は，ココヤシである。

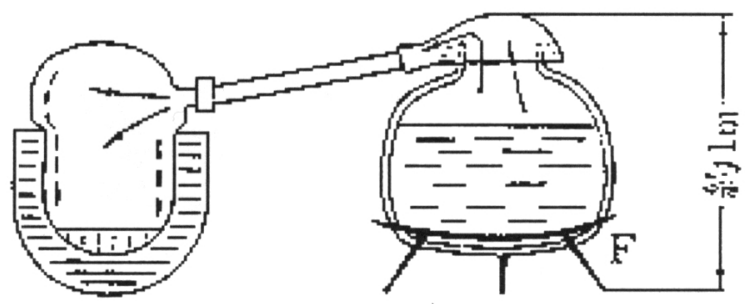

Fig. 18 Fig. 17 の復原図

同形の蒸留器をチトラルでも使用 宮森常男：醸造協会誌，Vol. 63，729-733， 1968

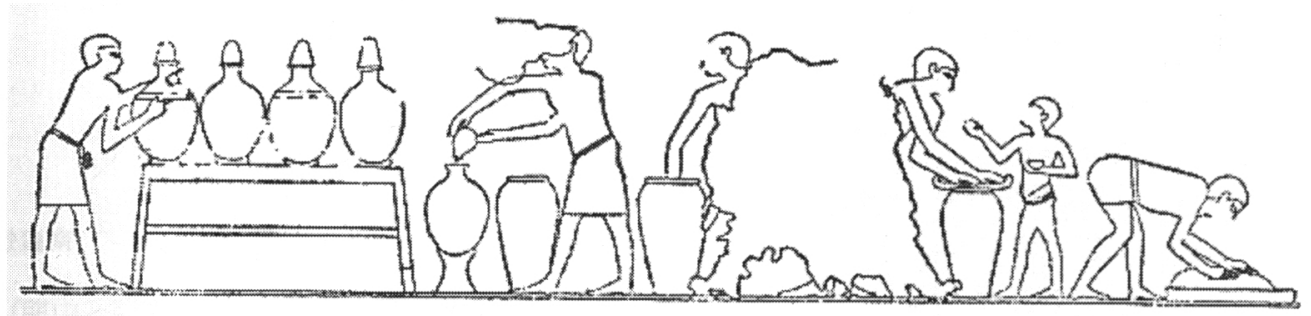

Fig. 19 ナツメヤシ酒の製造図

テーベの壁画 (BC1900 年頃)

加藤邦興：化学器械と装置の歴史，1978，クリオ，東京より転写 


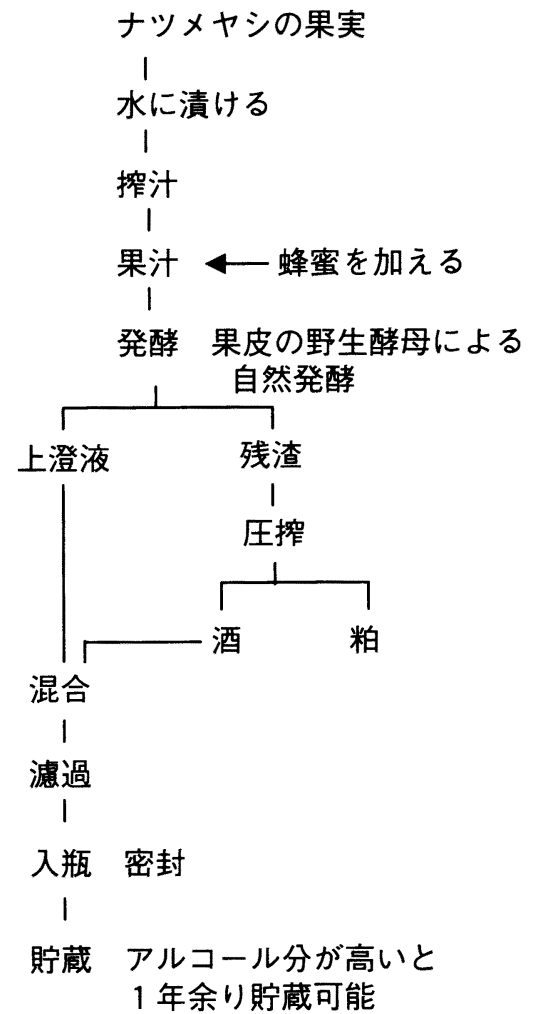

Fig. 20 ナツメヤシ酒の製造工程

テーベの壁画（BC1900 年頃）

加藤邦興：化学器械と装置の歴史, 1978, ク リオ，東京
(24)ファンスール王国（班卒兒国）：

青木, 愛宕, 馮「前述の樹からとった酒があ

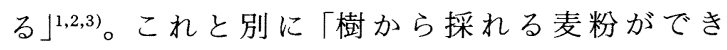
る」,2,3) とある。“前述の樹”とはサトウヤシかココヤ シ，“麦粉がとれる樹”はサゴヤシ Metroxylon sagu である。

(25) セイラン島（錫蘭島）：

青木, 愛宕, 馮「前述の樹液で造った酒」,2,3)。こ の地の樹は, サトウヤシかココヤシであろう。

(27)マーバール地方（馬八兒州）のさる小邑（マドラ ス南郊 $5 \mathrm{~km}$ の地マイラプール) :

愛宕「教会を管理しているキリスト教徒は，樹液の 出る木やファラオ胡桃を植えている」22。「樹液酒の出 る樹」とはサトウヤシ A renga pinnata，「ファラオ胡 桃」の採れる樹はココヤシ Cocos nucifera であろう。 （28）コイラム王国（俱藍国）（今のキーロン地方）：

青木，馮「楖子からとれる砂糖で造ったもので，早

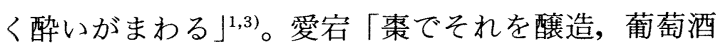
よりも酔いが早い」2)。前者と後者では異なる。楖子 糖が採れる1,3) のでサトウヤシか，パルミラヤシ Borassus flabellifer であろう。

『諸蕃志』（1225）マラバール・キーロン（馬刺八 兒・故臨国）の条に「楖子花汁に蜜糖を混和して酒を 醸す」 ${ }^{21)}$ とあるので, ヤシ樹液に楖子糖或は蜂蜜を加 えて発酵させた酒と思われる。この製法は, インドネ シアのアラック Arrack やフィリピンのランバノフ Lanbanogでも見られる (Fig. 21) ${ }^{22) 。 ~}$

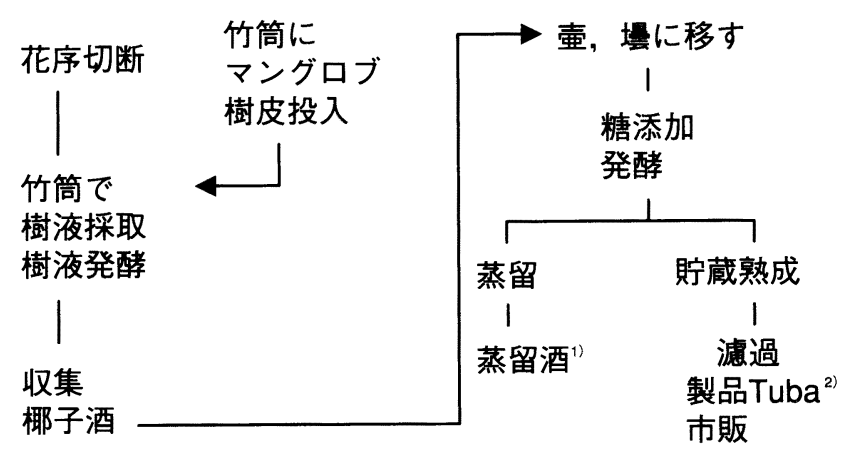

Fig. 21 楖子酒と楖子蒸留酒の製法

1）蒸留酒：フィリピンでは Lanbanog, インドネシ アでは Arrack

2）レイテ島：1 ケ月発酵酒は Tuba, 2～3 ケ月発酵酒 は Bahal，3 3 月貯蔵酒は Bahalina という。 
この酒は「早く酔いが回る」 $\rfloor^{1,2,3)}$ とあるから, 楖子 糖を加えて醸すのでアルコール度数が高い酒であった のであろう。

(29)ザンジバール島（僧祇抜兒島）：

青木, 馮「敤, 米, 香料, 砂糖などで酒を造る」1,3)。 愛宕「米に砂糖と香料を加えて一種の酒を造っており, なかなかの佳味で葡萄酒に劣らず酔いがまわる」2)。 愛宕は呆を挙げていないが, 青木, 馮は東を挙げてい る。砂糖は椰子糖であろう。

製法は不明であるが，19 世紀初頭インドネシアの ジャワで造られていたバタビア・アラック ${ }^{21)}$ 恐ら く同じような製法 (Fig. 22) で, 図中楖子酒は䊂椰 子酒, 糖蜜は砂糖, 発酵後は, 蒸留でなく濾過して飲 まれたのではないかと考えられる。香料は不明である。 (30)エシエル市（愛舎兒城）：

青木, 愛宕, 馮「砂糖, 米, 菓などでうまい酒を造

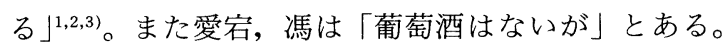
馮は「砂糖」でなく「糖」となっている。砂糖は楖子 糖であろう。ザンジバル島と同じような製法であっ たと考えられる。

\section{5. 上都, 大都の宮中の酒}

(12) シャンドウ市（上都城）：内モンゴリア樂河（luo he) 上流左岸, 夏の都
青木「いつも用いる酒, または香料入り酒」齐, 愛 宕「葡萄酒, 乳その他の飲み物」 $\rfloor^{2)}$, 馮「酒或其他良 好飲料」3) と訳している。

（13）ダイドウ市（干汗八里之契丹城）：現在の北京市, 冬の都

青木「葡萄酒や高価な香料入りの飲み物 ${ }^{11}$, 愛宕 $\lceil\text { 葡萄酒, 馬乳, 駱駝乳等の特製飲料 }\rfloor^{2)}$, 馮「酒, 精 貴之香料」3) と訳している。

大宴会では，馬乳，駱駝乳から造った特製飲料，葡 萄酒，香料入り酒などが準備されたようである。馬乳， 駱駝乳の特製飲料は乳酒（クミス）で，香料入り酒は 太禧白酒のような滋保酒であったと思われる。

『中国酒経』泉によれば，元代の宮廷用酒としては, 葡萄酒, 馬乳酒, 滋保酒である太禧白酒などが用いら れた。忽思慧は, 『飲膳正要』米谷品 $(1330)^{8)}$ の中で, 葡萄酒について「酒有数等, 有西番者, 有哈刺火者, 有平陽, 太原者, 其味都不及哈刺火者」と述べており, 味は哈刺火者（高昌国）のものが一番であると述べて いる。

馬乳酒は, 最も珍貴な国酒であったが, 大汗フビラ イ・カーンは, 嗜好に任せて馬乳酒を過飲したため足 疾リューマチが持病となったということである2)。

マルコ・ポーロはこれら以外の酒名を挙げていない。

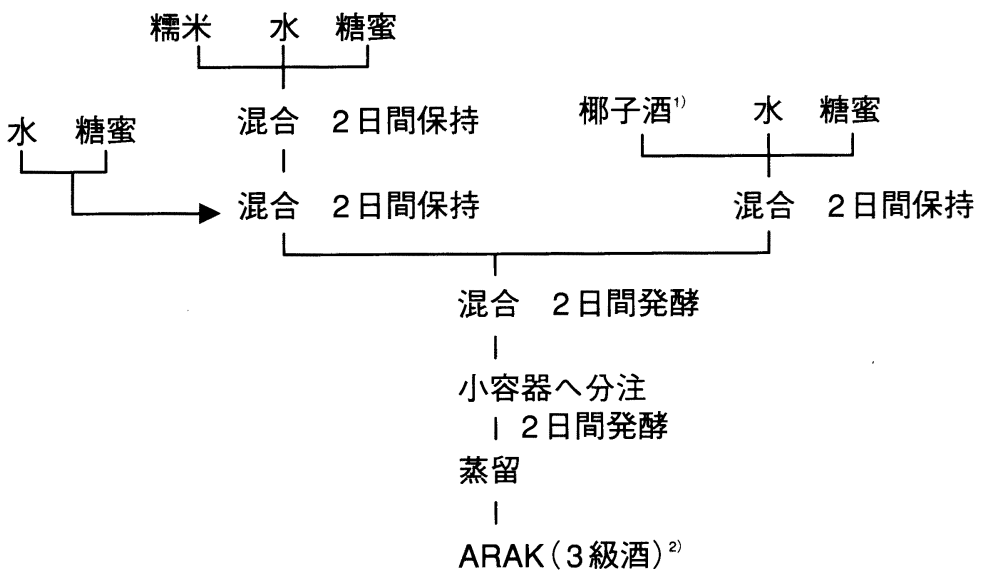

Fig. 22 Vatavian Arak の製法

1）ココヤシのトデイでもよい。

2） ARAK に加水再蒸留した酒 TAMPO（2 級酒）

TAMPO に加水再蒸留した酒 KIJI（1 級酒）

3）ジャワでは主に中国人によって造られた。

（文献 21 をもとに筆者が作図） 


\section{6. ケミス (忽迷思)}

マルコ・ポーロが通過したメソポタミア，中央アジ ア，インド，トルコには，既に乳製品があったが23， 彼はタタール人のクミスだけを取り上げている。

「ジンギスカーンを継承する諸カーン（成吉思汗後 之䐀君及韃靼人之風習)」の条で「彼らは家畜の肉と 乳, 狩編の獲物を常食とし, 飲物は馬乳 $ل^{1,2,3)}$ と述べ, 「タタール人の神抢よび彼らの掟 (鞋靼人之神道)」の 条で「馬乳は，白葡萄酒と同じょうにつくられ，クミ ズ ${ }^{1)}\left(\right.$ ケミス ${ }^{2)}$, 忽迷思 $\left.{ }^{3)}\right)$ と呼ばれ, まったく結構な 飲物」1) と紹介している。

戦闘時には,「必要とあれば, 一月でも食糧をもた ず走りつづけ，ただ乗馬の乳と狩猟の獲物だけで暮ら

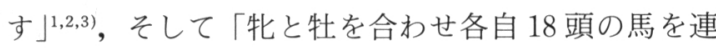
行し, 取り替えて騎乗し, 二個の革袋を提携し（Fig.

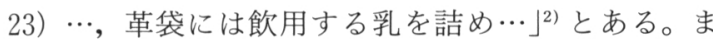
た「乳を煮立て, 表面の脂肪をとり, バターの原料に し, 残りの乳は太陽で乾かし糊状の乾燥乳にして携帯 して戦場に赴く。これを小型の皮袋水筒（Fig. 23） に入れ, 適当な水を加え鞍に吊るし騎馬の歩みで攪乱 され溶けあうのを待って飲む」2) とバターやチーズの 利用も記録している。
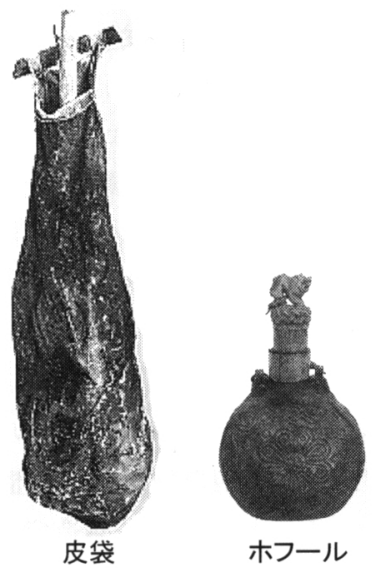

Fig. 23 馬乳酒用皮袋

皮袋：馬乳酒入れ

(国立博物館編集：国立博物館展示案内, 昭 和 61 年, (財千里文化財団) ホフール：馬乳酒や水入れ

(長谷川ら：草原の遊牧文明, 1998, 財千里文 化財団）
以上のように，遊牧民であるタタール人の生活が， 如何に家畜とその乳と密接な関係にあったかを生き生 きと今に伝えている。

\section{7. 当の他}

(31) 広大なルシア地方：

愛宕「住民は蜂蜜と稗を原料にしてセルヴィシアと 称する良質の強ビールを作り, 盛大な酒宴を催す」2)。 セルヴィシアの本体は不明である。

\section{IV. . と め}

13 世紀末のユーラシア大陸や, 南海の島々の酒類 と飲酒風俗を世界的見地から見聞し, 後世に書き残し たのはマルコ・ポーロが最初である。往路はオアシ ス・シルクロードを採り, 帰路は南海航路を採るこの 偉大な旅行を可能にした背景には, 蒙古帝国の成立と 牌符制度やキャラバン・サライ (隊商宿：駅伝制度） の整備があり, 唐末より発展した中国の造船技術と航 海術があった。

マルコ・ポーロは, 1270 から 1295 までの 25 年間 に見聞した酒として, 葡萄酒, 米酒, 蒸留酒, 楖子酒, 乳酒抢よびその他の酒を書き残している。

（1）葡萄, 葡萄酒は, 西アジアから中近東, 中央アジ アのシルクロード沿いのオアシス都市や国々を通 り中国まで分布して“ユーラシア大陸ワイン街 道”を形成していた。

（2）米酒は，雲南を含めた中国全土に分布して“米酒 文化圈”を形成していた。

（3）乳酒は，タタール人が飲用して “乳酒文化圏”を 形成していた。

（4）楖子酒は, 海のシルクロード沿いの諸島やインド 半島南部に, 東楖子酒はアフリカ東部海岸, アラ ビア半島, オルムズ海峡沿岸に分布して “楖子酒 文化圈”を形成していた。

（5）蒸留酒は，タイカンでのみで見られた。 $<$ 元宝酒造株式会社 $>$

\section{参 考 文 献}

1）青木富太郎訳：マルコ・ポーロ東方見聞録, 1991，(侏社会思想社，東京都

2）愛宕松尾訳：東方見聞録 I ；1994， II；1992， (侏) 平凡社, 東京都 
3）沙海昂註，馮承鈞訳：馬可波羅行紀，2004，中 華書局, 北京市

4）司馬遷『史記』: 巻 123 , 大宛列伝（西漢；BC 97 91)

5）欧陽修『新五代史』巻七四・四夷付録第三（北 宋, 1053)

6）李時珍『本草綱目』・谷部：巻 25 (明；1578 完 成, 1596 上梓)

7）朱宝康, 章克昌主編：中国酒経, 2000, 上海文 化出版社, 上海市

8）欧陽修等撰『唐書』巻 198 「高昌国伝」（宋； 1060)

欧陽修等撰：『唐書』巻 39 「地理誌」(宋； 1060)

忽思慧 :『飲膳正要』米谷品 $(1330)$

9）朱翼中『北山酒経』(巻二) (宋；1117)

10）稽含撰『南方草木状』(晋； 3 世紀後期)

11）紹興市政協文史資料委員会編：紹興酒文化, 1990，中国大百科全書出版社，上海分社

12）刑潤川: “我国蒸留酒起源于何時”, 微生物学通 報, Vol. 8，27-29，1981

13）敦煌研究院編：中国石窟安西榆林窟, 136 頁, 1997，文物出版社，(侏) 平凡社
14）菅間誠之助：見なおされる第三の酒，1975，㧣 朝日ソノラマ, 東京都

15）河北省長天集団公司：中国河北長天集団力夕口 グ, 8 16, 2006, 河北徐水康明南路 27 号

16）鄧少平，楊栄華：“李渡焼酒作業場遺跡につい て”第五回国際酒文化学術研討会論文集, $341 \sim 345,2004$, 日本醸造学会, 酒類総合研究 所

17）宮森常男: 禁酒国の酒を求めて, 日本醸造協会 誌，vol. 63，No.7，729〜733 (1968)

18）岩野貞雄：ワイン事典, 21 頁, 1979, 侏柴田 書店, 東京都

19）加藤国興：化学機械と装置の歴史，1978，クリ 才，東京都

20）山本紀夫，吉田集而：酒造りの民族誌，1995, (侏八坂書房, 東京都

21）松山晃：東南アジアの伝統食文化，1996，(侏ド メ久出版, 東京都

22）小崎道雄：“東南アジアの伝承ココナツ発酵商 品”（1）楖子酒，VESTA 食文化を考える， No. 2, 25, 1990

23）小崎道雄編著：乳酸発酵の文化譜，1997，侏中 央法規出版，東京都

\section{執筆者紹介（順不同・敬称略）}

高山卓美 $<$ Takumi TAKAYAMA $>$

昭和 10 年 4 月 18 日生まれ<勤務先とその所在地> 寶酒造株式会社元社員, 京都市下京区四条通鳥丸東入 長刀鉾 20 番地 $<$ 略歴 $>$ 昭和 34 年広島大学工学部卒業, 寶酒造入社, 平成 7 年同社退職, 退社後: 国立民族博 物館研究生, 金沢大学医学部臨時講師, JSV 会員,
JODC 会員, JICA 派遣専門技術者など歴任, 現在に至 る。賞罰: 農学博士取得, 日本醸造学会技術賞受賞 <抱負>特にアジアの伝統的酒類の製造法の調査研究 および蒸留酒の起源と伝播について調查研究するこ と。<趣味 $>$ 旅行 